\title{
Synthesis and Biological Evaluation of Indolyl Bis-chalcones as Anti-Breast Cancer and Antioxidant Agents
}

\author{
(1) Pravin S. Bhale, ${ }^{1, *}$ (1) Hemant V. Chavan, ${ }^{2}$ Rupali S. Endait, ${ }^{3}$ Ashok T. Kadam, ${ }^{1}$ Rajesh J. Bopalkar, ${ }^{1}$ Mandar S. Gaikwad ${ }^{1}$
}

\author{
1 Department of Chemistry, Yeshwantrao Chavan Mahavidyalaya, Tuljapur, Dist-Osmanabad-413601, Maharashtra, India \\ 2 Department of Chemistry, A.S.P. College, Devrukh, Dist-Ratnagiri-415 804, Maharashtra, India \\ 3 Department of Chemistry, Radhabai Kale Mahila Mahavidyalaya, Ahmednagar-414001, Maharashtra, India \\ * Corresponding author's e-mail address: bhale.ps@gmail.com
}

RECEIVED: March 23, 2021 * REVISED: July 21, 2021 * ACCEPTED: July 28, 2021

\begin{abstract}
A series of novel $\alpha$-cyano substituted indolyl bis-chalcones (3a-l) has been synthesized and evaluated for their in vitro antitumor activity against the human breast cancer MCF7 (estrogen receptor-positive) and normal Vero cell lines using sulforhodamine B (SRB) assay method. Compounds $3 \mathrm{a}, 3 \mathrm{c}$ and $3 \mathrm{~d}$ showed potent activity $\left(\mathrm{G} \mathrm{I}_{50}=11.7,15.3\right.$ and $17.9 \mu \mathrm{M}$ respectively) against the human breast cancer MCF7 cell line, which was almost as good as that of adriamycin $\left(\mathrm{Gl}_{50}=<0.1 \mu \mathrm{M}\right)$ whereas, screening against the normal Vero Monkey cell line showed moderate selectivity. Furthermore, all the synthesized compounds screened for their antioxidant potential against DPPH, NO, SOR, and $\mathrm{H}_{2} \mathrm{O}_{2}$ radicals. Most of the bis-chalcones exhibited significant DPPH (51.09-12.72\%) and NO (64.11-34.43\%) radical scavenging activity and modest activity against SOR (88.08-43.14 \%) and $\mathrm{H}_{2} \mathrm{O}_{2}(80.13-56.0 \%)$ radicals compared to the reference standard ascorbic acid $(40.78 \%, 42.63 \%$, $87.05 \%$, and $79.42 \%$ respectively). Current study provides impetus for the development of highly potent indolyl bis-chalcone derivatives as anticancer leads.
\end{abstract}

Keywords: indolyl bis-chalcone, breast cancer, anti-cancer activity, antioxidant activity.

\section{INTRODUCTION}

$\mathbf{P}$ RESENTLY cancer is deemed to a principal worldwide health problem that leads to death. ${ }^{[1]}$ Although considerable progress is made in controlling the progression of this devastating disease, till the date an entire cure for cancer remains a dream. Most of the cancer treatment is the use of surgery, radiation and chemotherapy. ${ }^{[2]}$ Most of the marketed chemotherapeutic agents suffer from serious and sometimes intolerable toxic effects. So, the development of novel anticancer agents is a crucial need of time. ${ }^{[3,4]}$ Chalcone is one of the important scaffold exhibiting diverse biological activities such as anti-inflammatory, ${ }^{[5]}$ antimalarial, ${ }^{[6]}$ antileishmanicidal, antiviral, antifungal, antibacterial and anticancer. ${ }^{[7,8]}$ Different type of structural alterations was performed in the chalcones primary structure either by varying the aryl moieties or the enone linker. Another tactic which is not that typical in literature is to change the $\alpha$ - position of the $\alpha, \beta$-unsaturated carbonyl system. This is a promising idea since it should have a direct and straightforward influence on the reactivity (Figure 1). Examples of the effect of $\alpha$-alteration on biological activity are also present. First time Edwards et al. reported that $\alpha$-substituted chalcones are more potent than their unsubstituted counter parts. ${ }^{[9]}$ Lawrence et al. also improved cytotoxic effects of $\alpha$ substituents such as phenyl, ester, cyano and fluoro groups on $\alpha, \beta$-unsaturated carbonyl system. ${ }^{[10]}$ Kumar et. al. also reported $\alpha$-cyano bis-indolyl chalcones as novel anticancer agents. ${ }^{[11]}$ Recently, our research group reported $\alpha$-cyano substituted bis-indolyl chalcone ${ }^{[12]}$ and extended conjugated indolyl chalcones as potent anti-breast cancer agents. ${ }^{[13]}$ In continuation of our constant efforts to discover a potent anticancer agents, ${ }^{[14-18]}$ herein we have synthesized a series of novel $\alpha$-cyano substituted indolyl bis-chalcone having phenyl ring as a spacer and in vitro evaluated for their antibreast cancer and anti-oxidant activity (Scheme 1). 


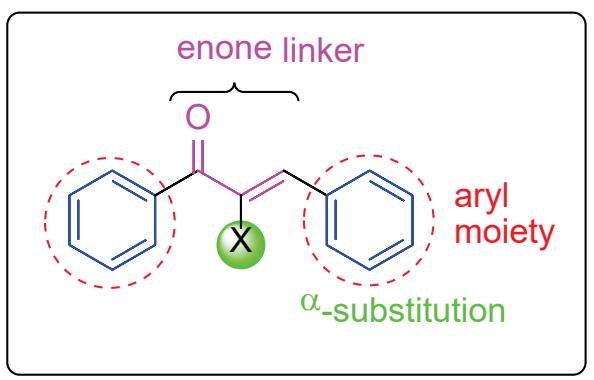

Figure 1. Chalcone framework.

\section{EXPERIMENTAL}

\section{Materials and Methods}

All the chemicals used for the synthesis were of synthetic grade and obtained from commercial sources. Development of the reactions was supervised by thin layer chromatography (TLC) using TLC plates (silica gel 60 F254, aluminum back, Merck). Visualization of TLC plate was achieved with UV light and or iodine vapors. All the solvents were dried using appropriate drying agents before use. Melting points were determined by open end capillary method and are uncorrected. All the ${ }^{1} \mathrm{H}$ NMR spectra were recorded in DMSO- $d 6 / \mathrm{CDCl}_{3}$ and chemical shifts in ppm were reported on instrument Bruker AV- $400 \mathrm{MHz}$, for ${ }^{1} \mathrm{H}$ NMR and $75 \mathrm{MHz}$ for ${ }^{13} \mathrm{C}$ NMR relative to TMS as an internal standard. The IR spectra were recorded on Shimadzu FT-IR spectrophotometer by using $1 \%$ potassium bromide discs. Mass spectra were obtained with a Shimadzu LCMS-2010EV (Shimadzu, Japan). Anticancer activities were performed under the supervision of Dr.JyotiKode, Scientific Officer, Tata Memorial Centre, Advanced Centre for Treatment Research and Education in Cancer (ACTREC), Kharghar, Navi Mumbai-410210.

\section{Synthesis}

\section{GENERAL PROCEDURE FOR THE PREPARATION OF 3-CYANOACETYLINDOLE (2)}

Indole $\mathbf{1}(0.117 \mathrm{~g}, 1 \mathrm{mmol})$ was added to a solution prepared by dissolution of cyanoacetic acid $(0.085 \mathrm{~g}, 1 \mathrm{mmol})$ in $\mathrm{Ac}_{2} \mathrm{O}$ $(10 \mathrm{ml})$ at $50{ }^{\circ} \mathrm{C}$. The solution was heated at $85^{\circ} \mathrm{C}$ for $5 \mathrm{~min}$. During that period 3-cyanoacetylindole 2 started to crystallize. After 5 more min, the mixture was allowed to cool and solid was collected, washed with methanol, and dried. ${ }^{[12,13]}$

\section{GENERAL PROCEDURE FOR THE PREPARATION OF INDOLYL BIS-CHALCONE (3a-I)}

To a mixture of 3-cyanoacetylindole $2(0.184 \mathrm{~g}, 1 \mathrm{mmol})$ in ethanol $(15 \mathrm{~mL})$ was added piperidine $(0.3 \mathrm{~mL})$ and stirred for $5 \mathrm{~min}$. Then isophthalaldehyde $(0.134 \mathrm{~g}, 1 \mathrm{mmol})$ was added and this mixture was heated to $80^{\circ} \mathrm{C}$ for $1-3 \mathrm{~h}$. After completion of reaction, the desired indolyl bis-chalcone (3a-l) was obtained as precipitate. The obtained precipitate was filtered, washed with water and oven dried. It was column purified by column chromatography using silica gel mesh size, 100-200 and elution with $10 \%$ ethyl acetate in hexane.

\section{(2E,2'E)-3,3'-(1,3-PHENYLENE)BIS(2-(1H-INDOLE-3- CARBONYL)ACRYLONITRILE) (3a)}

Pale yellow solid; $88 \%$; $264-266{ }^{\circ} \mathrm{C}$; IR $\left(\mathrm{cm}^{-1}\right)$ : $3251(\mathrm{NH})$, 2218 (CN), 1652 (C=O), 1593(C=C); ${ }^{1} \mathrm{H}$ NMR (DMSO-d 6,400 $\mathrm{MHz}): \delta=11.69(\mathrm{~s}, 2 \mathrm{H}, \mathrm{NH}), 8.29-8.27(\mathrm{~m}, 4 \mathrm{H}), 7.62(\mathrm{~d}, J=$ $8.4 \mathrm{~Hz}, 2 \mathrm{H}), 7.48(\mathrm{~d}, J=8.4 \mathrm{~Hz}, 2 \mathrm{H}), 7.29(\mathrm{~d}, J=8.0 \mathrm{~Hz}, 2 \mathrm{H})$, 7.20-7.16 (m, 5H), 6.64 (s, 1H); ${ }^{13} \mathrm{C}$ NMR (DMSO-d $\mathrm{d}_{6}, 75 \mathrm{MHz}$ ): $\delta=184.5,152.1,138.0,137.1,135.2,127.8,127.1,122.4$, $121.6,121.0,119.5,119.1,115.5,111.0,110.3,108.2$; HRMS: $467.4052(\mathrm{M}+\mathrm{H})$

\section{(2E,2'E)-3,3'-(1,3-PHENYLENE)BIS(2-(2-METHYL-1H- INDOLE-3-CARBONYL)ACRYLONITRILE) (3b)}

Yellow solid; $91 \%$; 302-304 ${ }^{\circ} \mathrm{C}$; IR $\left(\mathrm{cm}^{-1}\right)$ : $3258(\mathrm{NH}), 2200$ (CN), 1608 (C=O), 1545 (C=C); ${ }^{1} \mathrm{H}$ NMR (DMSO-d 6 , $400 \mathrm{MHz}$ ): $\delta=11.23(\mathrm{~s}, 2 \mathrm{H}, \mathrm{NH}), 8.18-8.15(\mathrm{~m}, 2 \mathrm{H}), 7.65(\mathrm{~d}, J=7.6 \mathrm{~Hz}$, $2 \mathrm{H}), 7.31-7.33(\mathrm{~m}, 2 \mathrm{H}), 7.16-7.13(\mathrm{~m}, 4 \mathrm{H}), 7.10-6.88(\mathrm{~m}$, $4 \mathrm{H}), 2.30\left(\mathrm{~s}, 6 \mathrm{H},-\mathrm{CH}_{3}\right) ;{ }^{13} \mathrm{C}$ NMR (DMSO-d $\left.6,75 \mathrm{MHz}\right): \delta=$ HRMS: $495.1816(\mathrm{M}+\mathrm{H})$

\section{(2E,2'E)-3,3'-(1,3-PHENYLENE)BIS(2-(5-BROMO-1H-} INDOLE-3-CARBONYL)ACRYLONITRILE) (3c)

Yellow solid; $89 \%$; 288-290 ${ }^{\circ} \mathrm{C}$; IR $\left(\mathrm{cm}^{-1}\right)$ : $3290(\mathrm{NH}), 3251$ $(\mathrm{NH}), 2212(\mathrm{CN}), 2163(\mathrm{CN}), 1702(\mathrm{C}=\mathrm{O}), 1690(\mathrm{C}=\mathrm{O})$; ${ }^{1} \mathrm{H}$ NMR (DMSO- $\left.\mathrm{d}_{6}, 400 \mathrm{MHz}\right): \delta=11.52(\mathrm{~s}, 2 \mathrm{H}, \mathrm{NH}), 8.48(\mathrm{~s}$, $2 \mathrm{H}), 8.34(\mathrm{~s}, 2 \mathrm{H}), 7.69-7.63(\mathrm{~m}, 2 \mathrm{H}), 7.34(\mathrm{~d}, J=8.0 \mathrm{~Hz}, 2 \mathrm{H})$, 7.09-6.99 (m, 3H), $6.94(\mathrm{~s}, 1 \mathrm{H}), 6.79(\mathrm{~d}, J=8.8 \mathrm{~Hz}, 2 \mathrm{H})$; ${ }^{13} \mathrm{C}$ NMR (DMSO- $\mathrm{d}_{6}, 75 \mathrm{MHz}$ ): $\delta=185.3,153.6,138.2,136.8$, 135.0, 128.2, 128.0, 127.7, 124.5, 122.6, 121.0, 115.4, 113.2, 113.0, 110.6, 108.2; HRMS: $622.8913(\mathrm{M}+\mathrm{H})$

\section{(2E,2'E)-3,3'-(1,3-PHENYLENE)BIS(2-(5-METHOXY-1H- INDOLE-3-CARBONYL)ACRYLONITRILE) (3d)}

Pale yellow solid; $92 \%$; $264-266{ }^{\circ} \mathrm{C}$; IR $\left(\mathrm{cm}^{-1}\right): 3281(\mathrm{NH})$, 3245 (NH), 2220 (CN), 1635 (C=O); ${ }^{1} \mathrm{H} \mathrm{NMR}\left(\mathrm{CDCl}_{3}, 400 \mathrm{MHz}\right)$ : $\delta=11.63($ broad s, $2 \mathrm{H}, \mathrm{NH}), 8.63(\mathrm{~s}, 2 \mathrm{H}), 8.43(\mathrm{~s}, 2 \mathrm{H})$, 7.83-7.76 (m, 1H), 7.67 (d, J = 2.0 Hz, 2H), 7.48-7.46 (m, 2H), $7.33(\mathrm{~d}, J=8.8 \mathrm{~Hz}, 2 \mathrm{H}), 7.22-7.18(\mathrm{~m}, 3 \mathrm{H}), 3.83(\mathrm{~s}, 6 \mathrm{H}$, $\left.\mathrm{OCH}_{3}\right) ;{ }^{13} \mathrm{C} \mathrm{NMR}\left(\mathrm{CDCl}_{3}, 75 \mathrm{MHz}\right): \delta$ = HRMS: $527.1714(\mathrm{M}+\mathrm{H})$

\section{(2E,2'E)-3,3'-(1,3-PHENYLENE)BIS(2-(5-CYANO-1H- INDOLE-3-CARBONYL)ACRYLONITRILE) (3e)}

Yellow solid; $87 \%$; $252-254{ }^{\circ} \mathrm{C}$; IR $\left(\mathrm{cm}^{-1}\right)$ : 3392(NH),2221 (CN), 2185 (CN), 1592(C=O); ${ }^{1} \mathrm{H}$ NMR (DMSO-d $6,400 \mathrm{MHz}$ ): $\delta=11.81($ broad s, $2 \mathrm{H}, \mathrm{NH}), 8.62(\mathrm{~s}, 2 \mathrm{H}), 7.76-7.69(\mathrm{~m}, 4 \mathrm{H})$, $7.47(\mathrm{~s}, 2 \mathrm{H}), 7.34(\mathrm{~d}, J=7.4 \mathrm{~Hz}, 2 \mathrm{H}), 7.26-7.13(\mathrm{~m}, 3 \mathrm{H}), 6.52$ 
(s, 1H); ${ }^{13} \mathrm{C}$ NMR (DMSO-d $6,75 \mathrm{MHz}$ ): $\delta=186.2,153.3$, $141.7,138.7,135.0,128.4,127.4,127.0,125.3,123.6$, $122.9,118.5,115.5,111.4,110.7,108.2,101.6$; HRMS: $517.1323(\mathrm{M}+\mathrm{H})$

\section{(2E,2'E)-3,3'-(1,3-PHENYLENE)BIS(2-(5-NITRO-1H-INDOLE- 3-CARBONYL)ACRYLONITRILE) (3f)}

Yellow solid; $89 \%$; $270-272{ }^{\circ} \mathrm{C}$; IR $\left(\mathrm{cm}^{-1}\right)$ : 3165(NH), 2216 (CN), 1607 (C=O), $1515\left(\mathrm{NO}_{2}\right) ;{ }^{1} \mathrm{H}$ NMR (DMSO-d $6,400 \mathrm{MHz}$ ): $\delta=11.61($ broad $\mathrm{s}, 2 \mathrm{H}, \mathrm{NH}), 8.68(\mathrm{~s}, 2 \mathrm{H}), 8.60(\mathrm{~s}, 2 \mathrm{H})$, 8.31-8.28 (m, 2H), 7.77-7.76 (m, 1H), 7.48-7.44 (m, 2H), 7.25-7.19 (m, 5H); ${ }^{13} \mathrm{C}$ NMR (DMSO- $\mathrm{d}_{6}, 75 \mathrm{MHz}$ ): $\delta=184.7$, $154.0,143.2,138.7,135.2,132.1,128.5,127.8,127.0$, $126.1,122.8,115.4,114.2,112.0,110.3,108.4$; HRMS: $557.4122(\mathrm{M}+\mathrm{H})$

\section{(2E,2'E)-3,3'-(1,3-PHENYLENE)BIS(2-(1-METHYL-1H-} INDOLE-3-CARBONYL)ACRYLONITRILE) (3g)

Pale yellow solid; $90 \%$; $264-266^{\circ} \mathrm{C}$; IR $\left(\mathrm{cm}^{-1}\right)$ : 2219 (CN), $1614(\mathrm{C}=0), 1593(\mathrm{C}=\mathrm{C}) ;{ }^{1} \mathrm{H}$ NMR (DMSO-d $\mathrm{d}_{6}, 400 \mathrm{MHz}$ ): $\delta=$ $8.62(\mathrm{~d}, J=6.5 \mathrm{~Hz}, 2 \mathrm{H}), 8.36(\mathrm{~s}, 2 \mathrm{H}), 7.45(\mathrm{~d}, J=7.6 \mathrm{~Hz}, 2 \mathrm{H})$, $7.57-7.52(\mathrm{~m}, 4 \mathrm{H}), 7.40(\mathrm{~d}, J=8.0 \mathrm{~Hz}, 4 \mathrm{H}), 7.21(\mathrm{t}, J=7.6 \mathrm{~Hz}$, 1H), $6.62(\mathrm{~s}, 1 \mathrm{H}), 3.65\left(\mathrm{~s}, 6 \mathrm{H}, \mathrm{NCH}_{3}\right) ;{ }^{13} \mathrm{C}$ NMR (DMSO-d 6,75 $\mathrm{MHz}$ ): $\delta=185.8,153.7,144.5,139.3,135.2,128.5,127.7$, $124.5,123.0,122.7,121.7,119.8,115.6,110.7,109.6$, 108.2, 32.5; HRMS: $495.1816(\mathrm{M}+\mathrm{H})$

\section{(2E,2'E)-3,3'-(1,3-PHENYLENE)BIS(2-(1,2-DIMETHYL-1H- INDOLE-3-CARBONYL)ACRYLONITRILE) (3h)}

Yellow solid; $92 \%$; $238-240{ }^{\circ} \mathrm{C}$; IR $\left(\mathrm{cm}^{-1}\right): 2215$ (CN), 1594 $(\mathrm{C}=\mathrm{O}), 1576(\mathrm{C}=\mathrm{C}) ;{ }^{1} \mathrm{H}$ NMR (DMSO- $\left.\mathrm{d}_{6}, 400 \mathrm{MHz}\right): \delta=8.14(\mathrm{~d}$, $J=6.4 \mathrm{~Hz}, 2 \mathrm{H}), 7.50(\mathrm{~s}, 2 \mathrm{H}), 7.50-7.42(\mathrm{~m}, 6 \mathrm{H}), 7.26-7.20$ $(\mathrm{m}, 3 \mathrm{H}), 6.70(\mathrm{~s}, 1 \mathrm{H}), 3.63\left(\mathrm{~s}, 6 \mathrm{H}, \mathrm{NCH}_{3}\right), 2.51\left(\mathrm{~s}, 6 \mathrm{H}, \mathrm{CCH}_{3}\right)$; ${ }^{13} \mathrm{C}$ NMR (DMSO-d $\mathrm{d}_{6}, 75 \mathrm{MHz}$ ): $\delta=185.3,168.6,154.0,140.3$, $135.8,128.5,127.5,126.2,122.8,121.8,121.0,119.7$, $119.1,115.5,108.7,103.0,29.4,12.2$; HRMS: 523.4807 $(\mathrm{M}+\mathrm{H})$

((2E,2'E)-3,3'-(1,3-PHENYLENE)BIS(2-(5-BROMO-1METHYL-1H-INDOLE-3-CARBONYL)ACRYLONITRILE) (3i) Yellow solid; $87 \%$; 268-270 ${ }^{\circ} \mathrm{C}$; IR $\left(\mathrm{cm}^{-1}\right)$ : 2226 (CN), 1642 (C=O), $1526(\mathrm{C}=\mathrm{C}) ;{ }^{1} \mathrm{H}$ NMR (DMSO- $\mathrm{d}_{6}, 400 \mathrm{MHz}$ ): $\delta=8.40$ (s, $2 \mathrm{H}), 7.59-7.50(\mathrm{~m}, 4 \mathrm{H}), 7.46(\mathrm{~d}, J=7.6 \mathrm{~Hz}, 2 \mathrm{H}), 7.31-7.23$ $(\mathrm{m}, 4 \mathrm{H}), 7.24(\mathrm{t}, J=7.6 \mathrm{~Hz}, 1 \mathrm{H}), 6.60(\mathrm{~s}, 1 \mathrm{H}), 3.61(\mathrm{~s}, 6 \mathrm{H}$, $\mathrm{NCH}_{3}$ ); ${ }^{13} \mathrm{C}$ NMR (DMSO-d, $75 \mathrm{MHz}$ ): $\delta=185.9,154.4$, $144.5,135.3,1351.1,128.7,128.2,127.5,124.3,122.7$, $121.0,115.6,113.2,110.7,110.0,108.5,32.6$; HRMS: $653.0009(M+1), 654.9952(M+2), 655.2287(M+3)$

(2E,2'E)-3,3'-(1,3-PHENYLENE)BIS(2-(5-METHOXY-1METHYL-1H-INDOLE-3-CARBONYL)ACRYLONITRILE) (3j) Pale yellow solid; 90\%; $270-272{ }^{\circ} \mathrm{C}$; IR $\left(\mathrm{cm}^{-1}\right): 2216$ (CN), $1621(\mathrm{C}=\mathrm{O}), 1595(\mathrm{C}=\mathrm{C}) ;{ }^{1} \mathrm{H} \mathrm{NMR}\left(\mathrm{CDCl}_{3}, 400 \mathrm{MHz}\right): \delta=8.40$ $(\mathrm{d}, J=4.0 \mathrm{~Hz}, 3 \mathrm{H}), 8.36(\mathrm{~s}, 2 \mathrm{H}), 8.27(\mathrm{dd}, J=8.0,1.6 \mathrm{~Hz}, 2 \mathrm{H})$, $8.00(\mathrm{~d}, J=2.8 \mathrm{~Hz}, 2 \mathrm{H}), 7.72(\mathrm{t}, J=8.0,7.6 \mathrm{~Hz}, 1 \mathrm{H}), 7.30(\mathrm{~d}$, $J=8.8 \mathrm{~Hz}, 2 \mathrm{H}), 7.04(\mathrm{dd}, J=8.8,2.4 \mathrm{~Hz}, 2 \mathrm{H}), 3.93(\mathrm{~s}, 12 \mathrm{H})$; ${ }^{13} \mathrm{C} \mathrm{NMR}\left(\mathrm{CDCl}_{3}, 75 \mathrm{MHz}\right): \delta=185.8,154.3,154.0,144.2$, $135.1,128.7,128.3,127.6,127.2,122.7,115.5,112.0$, 110.4, 109.3, 108.3, 104.2, 55.4, 32.1; HRMS: 555.2027 $(\mathrm{M}+\mathrm{H})$

(2E,2'E)-3,3'-(1,3-PHENYLENE)BIS(2-(5-CYANO-1-METHYL1H-INDOLE-3-CARBONYL)ACRYLONITRILE) (3k)

Yellow solid; $92 \%$; $260-262{ }^{\circ} \mathrm{C}$; IR ( $\left.\mathrm{cm}^{-1}\right)$ : 2226 (CN), 2217 (CN), $1661(\mathrm{C}=\mathrm{O}), 1621(\mathrm{C}=\mathrm{C}) ;{ }^{1} \mathrm{H}$ NMR (DMSO- $\mathrm{d}_{6}, 400 \mathrm{MHz}$ ): $\delta=8.32(\mathrm{~s}, 2 \mathrm{H}), 7.80(\mathrm{~d}, J=6.8 \mathrm{~Hz}, 2 \mathrm{H}), 7.49(\mathrm{~s}, 2 \mathrm{H})$, $7.41-7.30(\mathrm{~m}, 6 \mathrm{H}), 7.16(\mathrm{t}, J=7.6 \mathrm{~Hz}, 1 \mathrm{H}), 6.67(\mathrm{~s}, 1 \mathrm{H}), 3.68$ (s, 6H, NCH $)_{3} ;{ }^{13} \mathrm{C}$ NMR (DMSO-d $6,75 \mathrm{MHz}$ ): $\delta=186.1$, $154.2,144.2,140.5,135.0,128.5,127.4,127.0,125.2$, 123.6, 122.8, 118.4, 115.8, 111.7, 110.4, 108.1, 101.4, 32.5; HRMS: $545.4930(\mathrm{M}+\mathrm{H})$

\section{(2E,2'E)-3,3'-(1,3-PHENYLENE)BIS(2-(1-METHYL-5-NITRO- 1H-INDOLE-3-CARBONYL)ACRYLONITRILE) (3I)}

Yellow solid; $88 \%$; $246-248^{\circ} \mathrm{C}$; IR ( $\left.\mathrm{cm}^{-1}\right): 2284$ (CN), 1588 $(\mathrm{C}=\mathrm{O}), 1563(\mathrm{C}=\mathrm{C}), 1534 \quad\left(\mathrm{NO}_{2}\right) ;{ }^{1} \mathrm{H}$ NMR (DMSO-d 6 , $400 \mathrm{MHz}$ ): $\delta=9.10(\mathrm{~s}, 2 \mathrm{H}), 8.32(\mathrm{~s}, 2 \mathrm{H}), 8.10(\mathrm{~d}, J=8.0 \mathrm{~Hz}$, $2 \mathrm{H}), 7.93(\mathrm{~d}, J=8.0 \mathrm{~Hz}, 2 \mathrm{H}), 7.46(\mathrm{~s}, 2 \mathrm{H}), 7.48(\mathrm{~d}, J=7.6 \mathrm{~Hz}$, $2 \mathrm{H}), 7.22(\mathrm{t}, J=7.6 \mathrm{~Hz}, 1 \mathrm{H}), 6.39(\mathrm{~s}, 1 \mathrm{H}), 3.56\left(\mathrm{~s}, 6 \mathrm{H}, \mathrm{NCH}_{3}\right)$; ${ }^{13} \mathrm{CNMR}$ (DMSO-d $\mathrm{d}_{6}, 75 \mathrm{MHz}$ ): $\delta=185.3,154.1,144.0,142.5$, $135.6,132.2,128.5,127.2,127.0,126.2,122.4,115.2$, 114.0, 112.0, 110.3, 108.3, 32.6; HRMS: $585.5001(\mathrm{M}+\mathrm{H})$

\section{PROCEDURE OF THE SRB-ASSAY FOR ANTICANCER SCREENING}

Tumor cells (human breast cancer cell line MCF-7, Source: $\mathrm{NCl}$, USA and NCCS, Pune) were grown in tissue culture flasks in growth medium (RPMI-1640 with $2 \mathrm{mM}$ glutamine, $\mathrm{pH}$ 7.4, $10 \%$ fetal calf serum, $100 \mu \mathrm{g} \mathrm{mL} \mathrm{g}^{-1}$ streptomycin, and 100 units $\mathrm{mL}^{-1}$ penicillin) at $37{ }^{\circ} \mathrm{C}$ under the atmosphere of $5 \% \mathrm{CO}_{2}$ and $95 \%$ relative humidity employing a $\mathrm{CO}_{2}$ incubator. The cells at sub confluent stage were harvested from the flask by treatment with trypsin $(0.05 \%$ trypsin in PBS containing $0.02 \%$ EDTA) and placed in growth medium. The cells with more than $97 \%$ viability (trypan blue exclusion) were used for cytotoxicity studies. An aliquot of $100 \mu \mathrm{L}\left(5 \times 10^{3}\right.$ cells/well) of cells were transferred to a well of 96-well tissue culture plate. The cells were allowed to grow for one day at $37{ }^{\circ} \mathrm{C}$ in a $\mathrm{CO}_{2}$ incubator as mentioned above. The test materials at different concentrations $\left(10^{-7} \mathrm{M}, 10^{-6} \mathrm{M}, 10^{-5} \mathrm{M}, 10^{-4} \mathrm{M}\right)$ were then added to the wells and cells were further allowed to grow for another $48 \mathrm{~h}$. Suitable blanks and positive controls were also included. Each test was performed in triplicate. The cell growth was stopped by gently layering of $50 \mu \mathrm{L}$ of $50 \%$ trichloroacetic acid. The plates were incubated at $4{ }^{\circ} \mathrm{C}$ for 
an hour to fix the cells attached to the bottom of the wells. Liquids of all the wells were gently pipette out and discarded. The plates were washed five times with doubly distilled water to remove TCA, growth medium, etc. and were air-dried. $100 \mu \mathrm{L}$ of SRB solution ( $0.4 \%$ in $1 \%$ acetic acid) was added to each well and the plates were incubated at ambient temperature for half an hour. The unbound SRB was quickly removed by washing the wells five times with $1 \%$ acetic acid. Plates were air dried, tris-buffer $(100 \mu \mathrm{L}$ of $0.01 \mathrm{M}, \mathrm{pH} 10.4$ ) was added to all the wells and plates were gently stirred for 5 min on a mechanical stirrer. The optical density was measured on ELISA reader at $540 \mathrm{~nm}$. The cell growth at absence of any test material was considered $100 \%$ and in turn growth inhibition was calculated. $\mathrm{GI}_{50}$ values were determined by regression analysis.

\section{2,2-DIPHENYL-1-PICRYLHYDRAZYL (DPPH) RADICAL SCAVENGING ACTIVITY}

In this method, $0.1 \mathrm{mM}$ DPPH solution was prepared in methanol by adding $39.4 \mathrm{mg}$ of DPPH in $1000 \mathrm{~mL}$ of methanol, and to $0.5 \mathrm{~mL}$ of this solution, $1.5 \mathrm{~mL}$ of test compounds of the dissolved in DMSO were added at various concentrations of all $\left(1,10,100,500\right.$ and $\left.1000 \mu \mathrm{g} \mathrm{mL}^{-1}\right)$. The mixtures were shaken vigorously and allowed to stand at room temperature for 30 minutes. Then the absorbance was measured at $517 \mathrm{~nm}$ using a UV-VIS spectrophotometer (Shimadzu, spectrophotometer). Vitamin-C was used as standard compound. Reduction in absorbance by test compounds and indicates radical scavenging activity. The scavenging activity by the DPPH radical was determined by

$$
\mathrm{DPPH}_{\text {scavenging effect (\% inhibition) }}=\frac{A_{0}-A_{1}}{A_{0}} \cdot 100
$$

where $A_{0}$ is the absorbance of the control reaction, and $A_{1}$ is the absorbance test compound and vitamin $\mathrm{C}$.

\section{NITRIC OXIDE (NO) RADICAL SCAVENGING ACTIVITY}

The various concentrations of test compounds (as 1, 10, 100,500 , and $1000 \mathrm{\mu g} \mathrm{ml}^{-1}$ ) were prepared in ethanol. To $0.5 \mathrm{~mL}$ of $10 \mathrm{mM}$ sodium nitroprusside in phosphate buffered saline, to this, $1 \mathrm{~mL}$ of various concentrations of test compounds were mixed, and to this equal volume of freshly prepared Griess reagent was added, solution was then incubated at $25^{\circ} \mathrm{C}$ for $3 \mathrm{~h}$. Form this, $100 \mu \mathrm{L}$ of the reaction mixture was transferred to a 96-well plate, and the absorbance was read at $546 \mathrm{~nm}$ using a microplate reader (Biotek, Italy). Ascorbic acid was used as standard control.

The percentage of nitrite radical scavenging activity of test compounds was calculated by

$$
\mathrm{NO}_{\text {scavenging activity }}=\frac{A_{c}-A_{1}}{A_{c}} \cdot 100
$$

where $A_{c}$ is the absorbance of control, and $A_{1}$ is absorbance of test compounds.

\section{SUPEROXIDE RADICAL (SOR) SCAVENGING ASSAY}

The reaction mixture consisting of $1 \mathrm{~mL}$ of nitro blue tetrazolium (NBT) solution (156 mM NBT in phosphate buffer, $\mathrm{pH}$ 7.4), $1 \mathrm{~mL} \mathrm{NADH}$ solution ( $468 \mathrm{mM} \mathrm{NADH}$ in phosphate buffer, $\mathrm{pH} 7.4$ ), and $1 \mathrm{~mL}$ of synthetic compound $(1 \mathrm{mM})$ solution was mixed. The reaction was started by adding $1 \mathrm{~mL}$ of phenazine methosulfate (PMS) solution (60 $\mathrm{mM}$ PMS in phosphate buffer, $\mathrm{pH} 7.4$ ) to the mixture. The reaction mixture was incubated at $25^{\circ} \mathrm{C}$ for $5 \mathrm{~min}$ and the absorbance was measured at $560 \mathrm{~nm}$ against blank sample and compared with standards and percentage of inhibition was calculated using the same formula as above. Decreased absorbance of reaction mixture indicated increased SOR scavenging activity.

\section{HYDROGEN PEROXIDE SCAVENGING $\left(\mathrm{H}_{2} \mathrm{O}_{2}\right)$ ASSAY}

A solution of $\mathrm{H}_{2} \mathrm{O}_{2}(40 \mathrm{mM})$ is prepared in phosphate buffer (50 mM, pH 7.4). The concentration of $\mathrm{H}_{2} \mathrm{O}_{2}$ was determined by measuring absorption at $230 \mathrm{~nm}$ using a spectrophotometer. Synthetic compound ( $1 \mathrm{mM})$ in DMSO was added to $\mathrm{H}_{2} \mathrm{O}_{2}$ and absorbance was measured at 230 $\mathrm{nm}$ after $10 \mathrm{~min}$ against a blank solution containing phosphate buffer without $\mathrm{H}_{2} \mathrm{O}_{2}$. The percentage inhibition of $\mathrm{H}_{2} \mathrm{O}_{2}$ was calculated by formula,

$$
\text { \% inhibition }\left(\mathrm{H}_{2} \mathrm{O}\right)=\frac{A_{0}-A_{1}}{A_{0}} \cdot 100
$$

where $A_{0}$ is the absorbance of control and $A_{1}$ is the absorbance of test sample.

\section{RESULTS AND DISCUSSION}

\section{Chemistry}

In the current study, syntheses of novel $\alpha$-cyano substituted bis-chalcones (3a-I) were accomplished by the Knoevenagel condensation of 3-cyanoacetyl indoles $\mathbf{2}$ with substituted 3-isophthalaldehyde in the presence of piperidine in ethanol (Scheme 1). The starting compound, namely 3-cyanoacetyl indoles $\mathbf{2}$ were synthesized in good yield from the reaction of substituted indoles 1 with cyanoacetic acid in presence of acetic anhydride using the method described in the literature with minor modifications. ${ }^{[19]}$ The obtained crude products were purified by column chromatography using silica gel mesh size, 100-200 and elution with $10 \%$ ethyl acetate in hexane. The structures of target molecules were analyzed by IR, ${ }^{1} \mathrm{H}$ NMR and MS spectroscopic techniques. 


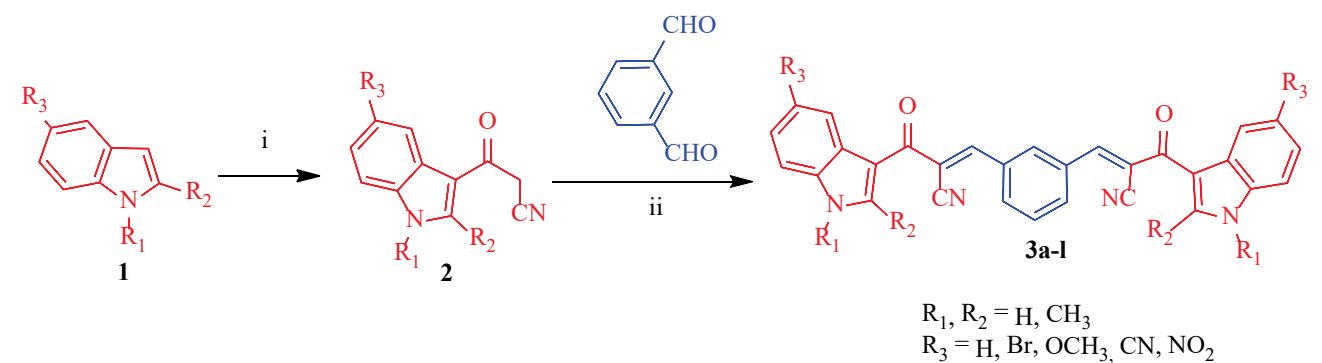

Scheme 1. Synthesis of novel $\alpha$-cyano substituted bis-chalcones. Reagents and conditions: i) $\mathrm{CNCH}_{2} \mathrm{COOH},\left(\mathrm{CH}_{3} \mathrm{CO}\right)_{2} \mathrm{O}, \mathrm{reflux}$; ii) piperidine, ethanol, $80^{\circ} \mathrm{C}, 1-3 \mathrm{~h}$.

\section{Biological Evaluation IN VITRO ANTICANCER ACTIVITY}

All the synthesized novel $\alpha$-cyano substituted bis-chalcones (3a-l) were evaluated for their in vitro anticancer activity against human breast cancer cell line MCF-7 by employing the sulforhodamine B (SRB) assay method. ${ }^{[20]}$ It is worth mentioning that most of the compounds were significantly cytotoxic against MCF-7 compared to the standard drug adriamycin, with the concentration of the drug that produced $50 \%$ inhibition of cell growth $\left(\mathrm{GI}_{50}\right)$. Three parameters such as $\mathrm{GI}_{50}, \mathrm{TGI}$ and $\mathrm{LC}_{50}$ were determined during the screening process and the results summarized in Table 1.

Compound $\mathbf{3 a}, \mathbf{3 c}$ and $\mathbf{3 d}$ exhibited potent activity $\left(\mathrm{Gl}_{50}=11.7,15.3\right.$ and $17.9 \mu \mathrm{M}$, respectively) against the MCF-7 cell line which was almost as good as that of standard drug adriamycin $\left(\mathrm{GI}_{50}=<0.1 \mu \mathrm{M}\right)$. On the other hand, all other $\alpha$-cyano substituted bis-chalcones showed weak cytotoxicity $\left(\mathrm{GI}_{50}=79.1->100 \mu \mathrm{M}\right)$ against MCF-7 cell line. A comparison of the $\mathrm{TGI}$ and $\mathrm{LC}_{50}$ concentrations of the compounds with Adriamycin were also done. All the $\alpha$-cyano substituted $b$ is-chalcones3a-I were inactive (TGI and $\mathrm{LC}_{50}>100 \mu \mathrm{M}$ ) like adriamycin against the MCF-7 cell line.

Many reported drugs impact the normal cell growth, which is a major disadvantage in the progress of anticancer drug development. Therefore, we have ensured the selectivity of some active compounds by in vitro screening against the normal Vero Monkey cell line. This cellular level screening results help to reveal the safety profile of active compounds. The cytotoxicity study showed that the $\mathrm{Gl}_{50}$ values for $\mathbf{3 a}, \mathbf{3 c}$ and $\mathbf{3 d}$ are $65.1,70.6$ and $55.3 \mu \mathrm{M}$, respectively (Table 1 ). This novel $\alpha$-cyano substituted bischalcones showed moderate selectivity against cancer lines over normal cell line.

Structure activity relationship (SAR) study reveals that the presence of electron donating groups at 5-position of indole holds better anticancer potential over electron withdrawing groups. Compound $\mathbf{3 a}$ with no substitution at 5 -position of indole ring exhibited potent activity $\left(\mathrm{Gl}_{50}=\right.$ 11.7 $\mu \mathrm{M}$ ) against MCF-7 cell line. Considering the type of substitution, compounds $\mathbf{3 c}$ and $\mathbf{3 d}$ containing bromo and methoxy group at 5-position of indole ring exhibited significant activity $\left(\mathrm{GI}_{50}=15.3\right.$ and $\left.17.9 \mu \mathrm{M}\right)$ against MCF-7 cell line, however, decrease in activity was observed with cyano substitution. Comparing of $\mathrm{Gl}_{50}$ values of $\mathbf{3 a - d}\left(\mathrm{GI}_{50}=\right.$ $11.7,47.2,15.3$ and $17.9 \mu \mathrm{M}$, respectively) and $3 g-j\left(G I_{50}=\right.$ $79.1->100 \mu \mathrm{M})$, we may presume that free $\mathrm{NH}$ of indole is essential for activity.

To confirm the effect $\alpha$-cyano substituted chalcone and $\alpha$-cyano substituted bis-chalcone on cytotoxic potential, we have prepared three simple $\alpha$-cyano substituted chalcone analogues of compounds $\mathbf{3 a}, \mathbf{3} \mathbf{c}$ and $\mathbf{3} \mathbf{d}$ by reacting suitable substituted 3-cyanoacetyl indole 2 with 3-(trifluoromethyl)benzaldehyde by refluxing in ethanol with the presence of piperidine. Comparison of the $\mathrm{Gl}_{50}$ values against MCF- 7 cancer cell line of $\alpha$-cyano substituted chalcone and $\alpha$-cyano substituted bis-chalcone were done. Bischalcone $\mathbf{3 a}, \mathbf{3 c}$ and $\mathbf{3 d}$ having phenyl ring as a spacer have increased the cytotoxic potential over their $\alpha$-cyano substituted mono-indolyl chalcone analogues (Figure 2).

\section{IN VITRO ANTIOXIDANT ACTIVITY}

The series of bis-chalcone (3a-I) were evaluated for their direct scavenging activity against a variety of reactive oxygen and nitrogen species such as 2,2-diphenyl-2picrylhydrazyl (DPPH), nitric oxide (NO) and superoxide (SOR), hydrogen peroxide $\left(\mathrm{H}_{2} \mathrm{O}_{2}\right)$. Free radical scavenging

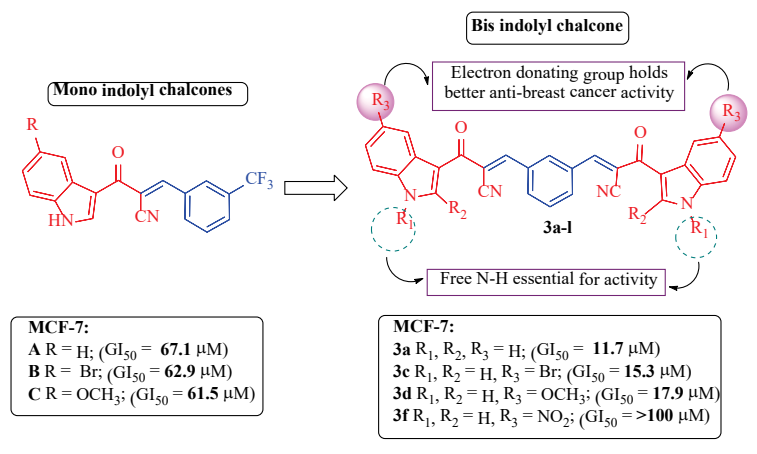

Figure 2. Comparison of anticancer activity of bis-indolyl chalcones over mono-indolyl chalcones. 
Table 1. In vitro anticancer screening of $\alpha$-cyano substituted bis-chalcones (3a-I) against human breast cancer cell line MCF-7a and monkey normal kidney cell line Vero.<smiles>[R]c1ccc2c(c1)c(C(=O)/C(N)=C/c1cccc(/C=C(\C)C(=O)c3c([Y])n([Y])c4ccc(Br)cc34)c1)c([R])n2[Z1]</smiles>

\begin{tabular}{|c|c|c|c|c|c|c|c|c|c|}
\hline \multirow{2}{*}{ Compound } & \multirow{2}{*}{$\mathrm{R}_{1}$} & \multirow{2}{*}{$\mathrm{R}_{2}$} & \multirow{2}{*}{$\mathrm{R}_{3}$} & \multicolumn{3}{|c|}{ MCF-7 } & \multicolumn{3}{|c|}{ Vero (normal) } \\
\hline & & & & $\mathrm{LC}_{50}^{(\mathrm{b})}$ & $\left.T G\right|^{(c)}$ & $\mathrm{Gl}_{50}{ }^{(\mathrm{d})}$ & $\mathrm{LC}_{50}$ & TGI & $\mathrm{Gl}_{50}$ \\
\hline 3a & $\mathrm{H}$ & $\mathrm{H}$ & $\mathrm{H}$ & $>100$ & $>100$ & 11.7 & $>100$ & $>100$ & 65.1 \\
\hline $3 b$ & $\mathrm{H}$ & $\mathrm{CH}_{3}$ & $\mathrm{H}$ & $>100$ & $>100$ & 47.2 & $>100$ & $>100$ & $>100$ \\
\hline $3 c$ & H & $\mathrm{H}$ & $\mathrm{Br}$ & $>100$ & $>100$ & 15.3 & $>100$ & $>100$ & 70.6 \\
\hline $3 d$ & $\mathrm{H}$ & $\mathrm{H}$ & $\mathrm{OCH}_{3}$ & $>100$ & $>100$ & 17.9 & $>100$ & $>100$ & 55.3 \\
\hline $3 e$ & H & $\mathrm{H}$ & $\mathrm{CN}$ & $>100$ & $>100$ & $>100$ & $>100$ & $>100$ & $>100$ \\
\hline $3 f$ & $\mathrm{H}$ & $\mathrm{H}$ & $\mathrm{NO}_{2}$ & $>100$ & $>100$ & $>100$ & $>100$ & $>100$ & $>100$ \\
\hline $3 g$ & $\mathrm{CH}_{3}$ & $\mathrm{H}$ & $\mathrm{H}$ & $>100$ & $>100$ & $>100$ & $>100$ & $>100$ & 95.2 \\
\hline $3 \mathrm{~h}$ & $\mathrm{CH}_{3}$ & $\mathrm{CH}_{3}$ & $\mathrm{H}$ & $>100$ & $>100$ & 79.1 & $>100$ & $>100$ & $>100$ \\
\hline $3 i$ & $\mathrm{CH}_{3}$ & $\mathrm{H}$ & $\mathrm{Br}$ & $>100$ & $>100$ & $>100$ & $>100$ & $>100$ & $>100$ \\
\hline $3 j$ & $\mathrm{CH}_{3}$ & $\mathrm{H}$ & $\mathrm{OCH}_{3}$ & $>100$ & $>100$ & 88.0 & $>100$ & $>100$ & 78.1 \\
\hline $3 k$ & $\mathrm{CH}_{3}$ & $\mathrm{H}$ & $\mathrm{CN}$ & $>100$ & $>100$ & $>100$ & $>100$ & $>100$ & $>100$ \\
\hline 31 & $\mathrm{CH}_{3}$ & $\mathrm{H}$ & $\mathrm{NO}_{2}$ & $>100$ & $>100$ & $>100$ & $>100$ & $>100$ & $>100$ \\
\hline Adriamycin & & & & 100 & 11.0 & $<0.1$ & $>100$ & 10.0 & $<0.1$ \\
\hline
\end{tabular}

(a) Concentrations in $\mu \mathrm{M}$.

(b) Concentration of drug resulting in a $50 \%$ reduction in the measured protein at the end of the drug treatment as compared to that at the beginning) calculated from $[(T i-T z) / T z] \times 100=-50$.

(c) Drug concentration resulting in total growth inhibition (TGI) will calculated from $T i=T z$.

(d) Growth inhibition of $50 \%\left(G I_{50}\right)$ calculated from $[(T i-T z) /(C-T z)] \times 100=50$.

activity was measured in terms of percent inhibition by using reported procedure in literature and results are presented in Table 2. All the synthesized $\alpha$-cyano substituted bis-chalcone have shown good to excellent scavenging activity against DPPH and NO radicals (Figure 3 ). The compounds $\mathbf{3 d}, \mathbf{3} \mathbf{a}, \mathbf{3} \mathbf{c}$ and $\mathbf{3} \mathbf{b}$ showed excellent DPPH free radical scavenging activity $(51.09,50.04,46.90$ and $41.10 \%$, respectively) as compared to standard ascorbic acid (AA) (40.78\%). Remaining compounds 3e-I showed moderate to weak DPPH free radical scavenging activity (12.72-37.90 \%). Compounds 3a-g showed excellent NO free radical scavenging activity (42.67-63.11 \%) as compared to standard ascorbic acid (42.63\%). All other compounds $3 \mathbf{h}-\mathbf{I}$ showed moderate NO free radical scavenging activity (34.43-41.30). Compound $\mathbf{3 b}$ exhibited excellent activity $(88.08 \%)$ against SOR radical as compared to standard ascorbic acid (87.05\%). All other compounds were moderate SOR scavengers (43.14-85.92 \%). Compound $\mathbf{3 f}$ have shown excellent $\mathrm{H}_{2} \mathrm{O}_{2}$ radical scavenging activity $(80.13 \%)$, whereas all other compounds showed moderate activity (56.00-73.23\%).
Table 2. In vitro antioxidant activity of curcumin analogues $(3 a-1)$.

\begin{tabular}{ccccc}
\hline \multirow{2}{*}{ Entry } & \multicolumn{4}{c}{ \% inhibition at 1 mM } \\
\cline { 2 - 5 } & DPPH & NO & SOR & $\mathrm{H}_{2} \mathrm{O}_{2}$ \\
\hline 3a & 50.04 & 62.64 & 80.16 & 66.11 \\
3b & 41.10 & 59.97 & 88.08 & 71.00 \\
3c & 46.90 & 44.18 & 60.55 & 69.05 \\
3d & 51.09 & 63.11 & 79.12 & 56.00 \\
3e & 37.90 & 59.25 & 54.99 & 59.12 \\
3f & 31.32 & 51.11 & 54.00 & 80.13 \\
3g & 30.11 & 42.67 & 81.40 & 71.14 \\
3h & 27.18 & 36.01 & 85.92 & 73.23 \\
3i & 29.13 & 37.17 & 43.14 & 64.57 \\
3j & 30.09 & 34.43 & 54.21 & 60.16 \\
3k & 12.72 & 40.00 & 65.12 & 56.98 \\
3l & 17.43 & 41.30 & 43.43 & 63.19 \\
AA & 40.78 & 42.63 & 87.05 & 79.42 \\
\hline
\end{tabular}




\section{CONCLUSION}

We designed and synthesized a series of novel $\alpha$-cyano substituted bis-indolyl chalcone derivatives and in vitro evaluated them for their cytotoxic potential against breast cancer (MCF-7) and normal Vero Monkey cell line. Compound 3a, 3c and $\mathbf{3 d}$ showed strong activity against breast cancer as good as adriamycin. In general, the presence of electron donating groups at 5-position of indole ring over electron donating groups and free $\mathrm{NH}$ of indole are essential for activity. Antioxidant potential of synthesized compounds was also evaluated and most of the compounds exhibited significant DPPH and NO radical scavenging activity. The present investigation has thus provided impetus for the design and development of potent bis-indolyl chalcone derivatives as anticancer leads.

Acknowledgment. Authors express deep thank to Tata Memorial Centre, Advanced Centre for Treatment Research and Education in Cancer (ACTREC), Kharghar, Navi Mumbai410210 for conducting the in vitro anticancer screening.

Supplementary Information. Supporting information to the paper is attached to the electronic version of the article at: https://doi.org/10.5562/cca3758.

PDF files with attached documents are best viewed with Adobe Acrobat Reader which is free and can be downloaded from Adobe's web site.

\section{REFERENCES}

[1] M. H. El-Wakil, H.M. Ashour, M.N. Saudi, A. M. Hassan, I. M. Labouta, Bioorg. Chem. 2017, 73, 154-169. http://dx.doi.org/10.1016/j.bioorg.2017.06.009

[2] U. Bughani, S. Li, H.C. Joshi, Recent Pat. Anti-Infect. Drug Discov. 2009, 4, 164-182.

https://doi.org/10.2174/157489109789318532

[3] E. Espinosa, P. Zamora, J. Feliu, M. G. Barón, Cancer Treat. Rev. 2003, 29, 515-523. https://doi.org/10.1016/S0305-7372(03)00116-6

[4] B. Mansoori, A. Mohammadi, S. Davudian, S. Shirjang, B. Baradaran, Adv. Pharm. Bull. 2017, 7, 339-348. http://dx.doi.org/10.15171/apb.2017.041

[5] C. Kontogiorgis, M. Mantzanidou, D. HadjipavlouLitina, Mini. Rev. Med. Chem. 2008, 8, 1224-1242. http://dx.doi.org/10.2174/138955708786141034

[6] A. Agarwal, K. Srivastava, S. Puri, P. M. S. Chauhan, Bioorg. Med. Chem. Lett. 2005, 15, 3133-3136. https://doi.org/10.1016/j.bmcl.2005.04.011

[7] X.-F. Liu, C.-J. Zheng, L.-P. Sun, X.-K. Liu, H.-R. Piao, Eur. J. Med. Chem. 2011, 46, 3469-3473. https://doi.org/10.1016/j.ejmech.2011.05.012
[8] M. Zoldakova, Z. Kornyei, A. Brown, B. Biersack, E. Madarász, R. Schobert, BiochemPharmacol. 2010, 80, 1487-1496.

https://doi.org/10.1016/j.bcp.2010.07.046

[9] M. L. Edwards, D. M. Stemerick, P.S. Sunkara, J. Med. Chem. 1990, 33, 1948-1954.

https://doi.org/10.1021/jm00169a021

[10] N. J. Lawrence, R. P. Patterson, L.-L. Ooi, D. Cook, S. Ducki, S., Bioorg. Med. Chem. Lett. 2006, 16, 5844-5848.

https://doi.org/10.1016/j.bmcl.2006.08.065

[11] D. Kumar, N. Maruthi Kumar, M. P. Tantak, M. Ogura, E. Kusaka, T. Ito, Bioorg. Med. Chem. Lett. 2014, 24, 5170-5174. https://doi.org/10.1016/j.bmcl.2014.09.085

[12] P. S. Bhale, H. V. Chavan, S. B. Dongare, S. N. Shringare, Y. B. Mule, P. B. Choudhari, B. P. Bandgar, Current Bioactive Compounds 2018, 14, 299-308. https://doi.org/10.2174/157340721366617042811 2855

[13] P. S. Bhale, H. V. Chavan, S. B. Dongare, S. N. Shringare, Y. B. Mule, S. S. Nagane, B. P. Bandgar, Bioorg. Med. Chem. Lett. 2017, 27, 1502-1507. https://doi.org/10.1016/j.bmcl.2017.02.052

[14] S. N.Shringare, H.V. Chavan, P. S.Bhale, S.B.Dongare, Y. B. Mule, N. D.Kolekar, B. P.Bandgar, Croat. Chem. Acta 2018, 91, 357-366.

https://doi.org/10.5562/cca3393

[15] S. B. Dongare, B. P. Bandgar, P. S. Bhale, S. N. Shringare, H. V. Chavan, Croat. Chem. Acta 2019, 92, 1-9. https://doi.org/10.5562/cca3418

[16] S. N. Shringare, H.V. Chavan, P. S. Bhale, S.B. Dongare, Y. B. Mule, S. B. Patil, B. P. Bandgar, Med. Chem. Res. 2018, 27, 1226-1237. https://doi.org/10.1007/s00044-018-2142-8

[17] P. S. Bhale, B. P. Bandgar, S. B. Dongare, S. N. Shringare, D. M. Sirsat, H. V. Chavan, Phosphorus, Sulfur, and Silicon and the Related Elements 2019, 194, 843-849. https://doi.org/10.1080/10426507.2019.1565760

[18] P. S. Bhale, H. V. Chavan, S. B. Dongare, S. T. Sankpal, B. P. Bandgar, Anti-Cancer Agents in Medicinal Chemistry 2018, 18, 757-764.

https://doi.org/10.2174/187152061766617091212 4258

[19] J. Slatt, I. Romero, J. Bergman, Synthesis, 2004, 16, 2760-2765.

https://doi.org/10.1055/s-2004-831164

[20] P. Skehan, R. Strong, D. Scadiaro, A. Monks, J. McMahon, D. Vistica, J. T. Warren, H. Bokesch, S. Kenney, M. R. Boyed, J. Natl. Cancer Inst. 1990, 82, 1107-1112.

https://doi.org/10.1093/jnci/82.13.1107 